\title{
INFORMATION VALUE OF SIGNS AN IMAGE AND TEXT
}

\section{Anton STOLÁR}

Resumé: The article follows up the topic of meta-education. In the first part we compare the potential of signs of image and text to bear information (chapters 1-4). Further, we analyze the particularities of the recognition process from the aspect of semiotics and informatics (chapters 5-6). We implement and substantiate the functional criterions for the interdisciplinary term informative value of sign as the qualifier of information. In the last part we describe the function of the informative value of sign in the process of information sharing and suggest further functions of meta-interface.

Key words: sign, cognition, image, semiotic, text, information value.

\section{INFORMAČNÁ HODNOTA ZNAKOV OBRAZU A TEXTU}

\begin{abstract}
V prvých častiach v skratke porovnáme potenciál znakov obrazu a textu niest' informačný obsah (kapitoly 1-4). V d'alšich častiach analyzujeme špecifiká procesu poznávania z perspektívy semiotiky a informatiky (kapitoly 5-7). Zavádzame a odôvodňujeme funkčné kritériá pre interdisciplinárny pojem informačná hodnota znaku ako kvantifikátora informačného obsahu. V poslednej časti popisuje vzt’ah informačnej hodnoty znaku $v$ procese poznávania a navrhuje d’alšie funkcie metarozhrania.
\end{abstract}

Kl'účové slová: znak, poznávanie, obraz, semiotika, text, informačná hodnota.

1 Úvod

Ak sme v predchádzajúcom článku o metavzdelávaní načrtli funkcie metarozhrania [1], zámerom tohto príspevku je bližšie analyzovat' interakciu medzi účastníkom a znakmi $\mathrm{v}$ procese získavania poznatkov. Proces budeme skúmat' z perspektívy semiotiky, teórie informácie, informačného dizajnu takým spôsobom, aby nám ich medziodborový priesečník načrtol akou cestou sa majú uberat' metódy označovania, reprezentovania a transferovania niečoho $\mathrm{z}$ domén poznania [2]. Vedl'ajším ciel'om článku je uviest' čitatel'a do oblasti tvorby „obrazotextov“, ktoré podl'a Flussera [3] a iných budú podstatným nosičom informácií v digitálnych médiách a v neposlednom rade rozšírit' povedomie society informatikov o humanitných aspektoch pojmu informácia.

\section{Text verzus obraz}

Žijeme vo vizuálnom veku? Prevezme časom obraz všetky funkciu textu? Nesplynie text a obraz $\mathrm{v}$ metarozhraní do jedného kódu a vráti nás do dôb používania nearbitrárnych znakov pred Babylonom (lingua adamica), ked' forma znaku bola v súlade s povahou označeného?

Od dôb historických (prehistória nepoznala písmo) sú obraz a text nesporne najfrekventovanejšie formy zaznamenávania a prenosu poznania. Tieto médiá spočiatku jednotné (piktogram) časom menili nielen svoju formu (ideogram, logogram, fonogram...), ale vd’aka špeciálnym nosičom (tlač, Internet, družica Pioner10...) aj schopnost' zväčšovat' akčný rádius pôsobenia zakódovanej správy $\mathrm{v}$ časopriestore.

Zatial čo písmové formy (dizajn písma či štruktúra textov) sa menili relatívne pomaly, dokonca pomalšie ako sa menil prirodzený jazyk, informácie vo forme obrazu sa vplyvom techník a technológií spracovávali a spracovávajú čoraz rôznorodejšie (video, fotografia, $3 \mathrm{D} \mathrm{TV}$, virtuálna realita...) a vd'aka sofistifikovanej mediácii (satelitný prenos, guerillový marketing...) sú šírené omnoho rýchlejšie a cielenejšie. Inak povedané na rozdiel od textu, ktorého formy „predvádzania“ sa zdajú byt' vyčerpané, obraz ponúka $\mathrm{v}$ súvislosti s rozvojom digitálnych techník stále nové impulzy na svoje sebazdokonal'ovanie.

\section{Tradícia textu}

Text pôsobí ako tichá šedá plocha, do ktorej môžeme vel'mi úspornými prostriedkami zakódovat' aj vel'mi zložitý obsah. Aj ked' ho môžme chápat' ako istú formu grafiky, od obrazu sa líši vo viacerých momentoch. Vzniká a číta sa z lineárne zoradených grafických znakov, ktoré 
zaznamenávajú tok reči alebo myšlienok a ich zápis podlieha pravidlám gramatiky. Ani celý text, ale ani dve jednotky významu-slová nevieme prečítat' naraz. Znaky čítame postupne sekvenčne a celkový význam-kontext pochopíme až po prečítaní celého textu. Interpretáciu jednotiek textu prevádzame tzv. viacstupňovým označovaním (semiózou), kde grafickú podobu najskôr označujeme akustickým obrazom [4], ktorému až následne prirad’ujeme význam. Dôkaz existencie akustického obrazu je naša schopnost' rozprávat' sa sami so sebou.

Funkcia väčšiny textov, ak vynecháme synonymá a homonymá, je pomenovávat' skutočnosti pokial' možno jednoznačne [5]. Čím sa viac vzd'al'ujeme od označovania fyzických objektov a situácií a blížime sa do sveta abstraktných pojmov, sylogizmov a ideí sa zdá byt' text nenahraditel'nejší. Zo sémantického hladiska je sila textu v jeho opisnosti, schopnosti redukovat' viacvýznamovost' pri označovaní. $\mathrm{S}$ rastúcim počtom slov o niečom síce hustne kontext a čistí sa celkový zmysel, no v dlhých textoch sa rozpúšt'a účinok.

Nové médiá a spôsoby zobrazovania ale aj rýchlejšie tempo života priniesli aj nové textové formy. Mení sa spôsob spracovania ale aj ich komunikačná schopnost'. Každý z nás dokáže nasádzaný text istým spôsobom vizuálne priblížit' k obrazu. Stačí premysliet' nastavenie sadzbových parametrov a zalomit' ho kreatívnejšie. Texty už nemusia byt' monotónnou šedou štruktúrou, ktorú musíme preosiat očami. $\mathrm{Na}$ zobrazovacích jednotkách vytvárajú priestorové diagramy, ktoré môžeme čítat' viacerými spôsobmi. Animácia, jednoduché nastavenie farieb či štruktúr, bohatý výber fontov, umožňujú rozpohybovat' farebné línie slov do obrazcov evokujúcich priestorové kaligramy.

Text však má aj svoje limity. Aj napriek vel'kej snahe ponúknut' na zobrazovacích jednotkách oku prijatel'né písmo, čítanie znakov stále spôsobuje únavu. To núti tvorcov e-obsahu v porovnaní s printovými verziami zhutňovat' rozsiahle texty do kratších hypertextovo prepojených syntaktických štruktúr. V nových médiách hrajú hlavnú úlohu kratšie textové bloky, titulky, s rôznym nastavením parametrov.

Slová textov sú zložené ani nie $\mathrm{z}$ troch tuctov abstraktných tvarov-litier alfabety. Ich kombináciou dokáže každý jazyk využívajúci fonetický princíp, vyskladat' desat'tisíce originálnych slov, ktorých význam sa musíme naučit'. Napr. akademický slovník slovenského jazyka eviduje 250000 slov [6]. K tomuto počtu treba prirátat' aj systém desiatkovej sústavy, ktorý rozširuje potenciál nezobrazujúcich symbolov o rôzne druhy výpočtov, ale aj presné dáta.

\section{Vitálnost’ obrazu}

Znaky obrazov nemajú na rozdiel od textu až takú historickú skúsenost' ani konvencie či stratégiu ako prezentovat' zložité posolstvá efektívnym spôsobom. Napriek tomu sme $\mathrm{v}$ súčasnosti svedkami nárastu množstva obrazov. Príčin je viacero. Súvisia jednak $\mathrm{s}$ dostupnost'ou aparátov na záznam a tvorbu obrazov, zdokonal'ovaním špeciálnych optickoelektronických techník, ale aj vyššou atraktívnost’ou vizuálnych vnemov pre náš zrak. Obraz má teda väčšie predpoklady zvyšovat' svoj sémantický potenciál - reprezentovat' rôzne typy dát $\mathrm{s}$ rôznorodým poslaním. $\mathrm{Z}$ ontologického pohl'adu je to teda fatálne uzavretý kruh (príčina/dôsledok/príčina...), v ktorom nárast množstva, atraktívnost' a rôznorodost' obrazov generuje ich sémantickú potencionalitu a naopak.

Obrazy dokážu skvelo predviest' 3Dmodely, procesy odohrávajúce sa v čase, znázornit' vzt'ahy v priestore, reprezentovat' koncepty [7] či vyvolat' emócie. Prinášajú informácie $\mathrm{z}$ d'alekých planét aj z detailov mikrosveta. Akonáhle však majú označit' komplikovaný pojem (pravdepodobnost') alebo niečo abstraktné (slobodná vôl'a) prestávajú byt' účinné.

$\mathrm{Na}$ reprezentovanie toho čo je mienené použivajú repertoár grafických znakov (fyzických kódov), ktoré semiotika roztriedila podl'a toho, čo a akým spôsobom označujú niečo $\mathrm{z}$ domén poznania. $\mathrm{Z}$ možných stavov vyčírime nasledovné typy korešpondencie [8] medzi tým čo je ukázané a tým čo je mienené:

- ikonické znaky sa podobajú na niečo z reality alebo štruktúrou odkazujú na niečo z fyzického časopriestoru,

- metaforické znaky využívajú nejaký typ analógie s realitou napr. okno pre Windows jablko pre Apple,

- konvenčné znaky využívajú dohodnutý význam,

- metonymické znaky sú postavené na mentálnej asociácii. 


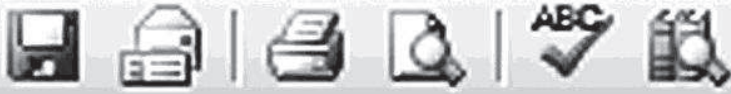
\% 糔

Obr 1: Ovládacie prvky Wordu sú vybudované z ikon (kôš, disketa, lupa, tlačiarnička), metafor (ret'az so zemegul'ou, štetec), metonymii (nožnice, obálka) a konvenčných znakov (šipky na posun vpred vzad otáznik, litery).

Semiotika delí grafické znaky okrem typu korešpondencie obr. 1, ktorý je pre označovanie klúčový, aj podl'a spôsobu vyjadrenia [9]. V tomto kritériu je rozhodujúca miera podobnosti znaku s tým čo označujú. Či sa ich forma (štruktúra) blíži k realite alebo na druhej strane či ich forma je symbolická. (napr. označenie rádioaktívneho odpadu). $\mathrm{V}$ tomto prípade znaky delíme na zobrazujúce, ktoré imitujú niečo konkrétne (ikona, metafora, metonymia, rébusy, konvenčné) a nezobrazujúce (abstraktné tvary, symboly, vrátane slov a čísel). Ako vidíme na opačnom konci pomyselnej osi podobnosti stoja slová a textové formy obr. 2. Na poznanie významu nezobrazujúcich znakov už nestačí dennodenná skúsenost' s okolím ani logika sedliackeho rozumu, významy nezobrazujúcich znakových systémov sa musíme učit’

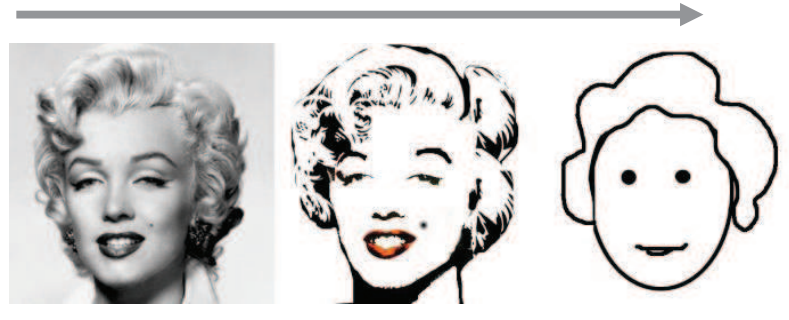

Obr 2: miera abstrahovania-dizajnovania od zobrazujúcej fotografie po symbol.

Jednotlivé znaky umiestnené $\mathrm{v}$ obrazoch sú vybudované z „" -výrazových prostriedkov: tvar, textúra, vel'kost', farba, svetlost', orientácia, umiestnenie na strane, [10]. Tieto atribúty tvoria vizuálny stavebný materiál, z ktorého sú vytvárané znakové systémy ako súbory dohodnutých alebo intuitívne vnímaných pravidiel (napr. dopravné značky).

Porozumiet' reči obrazov vyžaduje poznanie pravidiel vizuálneho jazyka, teda vyžaduje určitú vizuálnu gramotnost'. Jazyku obrazu je „l'ahké“ porozumiet'. Je prístupnejší, ale aj univerzálnejší ako jazyk arbitrárnych symbolov textu (slovo pes nevyzerá ako pes). $Z$ toho dôvodu inštitút školy mylne predpokladá, že jazyk obrazov pochopíme spontánne-skúsenost'ou a učit' sa ho nemusíme.

Keby sme mali zosumarizovat' základné jednotky vizuálneho jazyka, zaradili by sme tam pár tisíc jednoznačne rozpoznatel'ných tvarov ako siluety postáv a tvárí, známe objekty architektúry, fauny, flóry, úžitkových predmetov atd’., s ktorými máme vizuálnu skúsenost'. Čo sa týka farieb, aj ked' ich vieme namiešat' na tisícky (15,6 mil. farieb na monitore je pre oko príliš vysoká latka) počet farieb, ktoré môže neškolený jedinec jednoznačne rozpoznat' (nie rozlíšit!)je paradoxne len cca 20-30 [11].

Aj ked' sa nám zdá, že repertoár výrazových prostriedkov obrazov je pestrý a rôznorodý, množstvo prakticky rozpoznatel'ných znakov je relatívne obmedzený. Rozmanitost' obrazov sa dosahuje hlavne kombináciou a variabilitou vizuálneho materiálu v originálnych znakových štruktúrach, $\mathrm{v}$ možnosti narábat' s iluzívnym priestorom na ploche a možnost'ou rozpohybovania grafických prvkov v obraze.

Tak ako pri texte aj osamotený grafický znak môže byt interpretovaný viacerými spôsobmi (homonymá) tak ako na druhej strane, viacero znakov môže mat' približne rovnaký význam (synonymá). Červená na semafore môže podl'a typu korešpondencie znamenat' stop ako dohodnutý znak, ale môže označovat' aj krv ako ikonický znak.

\section{Semiotika verzus informatika}

Konvenčná semiotika sa pozerá na znak z troch aspektov: syntaktického, sémantického, a pragmatického [4]. Z pohl'adu syntaxe najviac informácií získa ten, kto je schopný odseparovat od pozadia čo najviac znakov a zmyslami ich identifikovat'. Zo sémantického aspektu najviac ziska ten, ktorý má vedomosti o tom čo jednotlivé znaky a vztahy medzi nimi znamenajú. Pragmaticky najviac z podnetov ziska ten účastník, ktorý dokáže zvážit' aktuálnu dôležitost' prijatých informácii a integrovat' ich do socio-kultúrnych súvislostí.

Ciele a povaha informatiky sú v tejto komunite všeobecne známe, preto len poznamenáme, že informačné vedy $\mathrm{v}$ snahe predmet svojho záujmu kvantifikovat', redukujú zložité a komplexné na izolované, abstraktné jednotky, ktoré potom dokážu jazykom logiky jednoznačnejšie formalizovat'. Aj ked' 
informačný obsah, informačný tok dokážu exaktné vedy kvantifikovat' celkom presne napr. televízny obraz prenáša viac než $10^{6}$ bit.s $^{-1}$ [12], nezohl'adňujú pragmatickú stránku bio-psychosociálnej zameranosti účastníka.

Semiotika systematizuje empirické skúsenosti z označovania, informačné vedy postupujú exaktne, ked' riešia štatistickú pravdepodobnost' výskytu znaku na vstupe do systému [13]. Semiotika pozoruje, analyzuje, dedukuje zovšeobecňuje kauzálne javy spojené s označovaním akoby zvonka, teória informácie vytvára štatistické modely správania sa konkrétneho systému. Znaky analyzujú inou metódou a odlišným jazykom. To čo majú spoločné, môžeme zredukovat' na axiómu informácia spôsobuje zmenšenie neusporiadanosti (entrópie) systému.

Pokúsime sa interdisciplinárne premostit' semiotiku sinformatikou a vytvorit' tak objektívnejšiu metódu, ktorá nám pomôže lepšie kryštalizovat' inštrumentárium metarozhrania. Aby sme sa nepošmykli, budeme sa pridŕžat' Aristotelovej obecnej až ideologickej definícii „rerum imagines animo informare“ a to, že informácia „pretvára dušu obrazmi veci““.

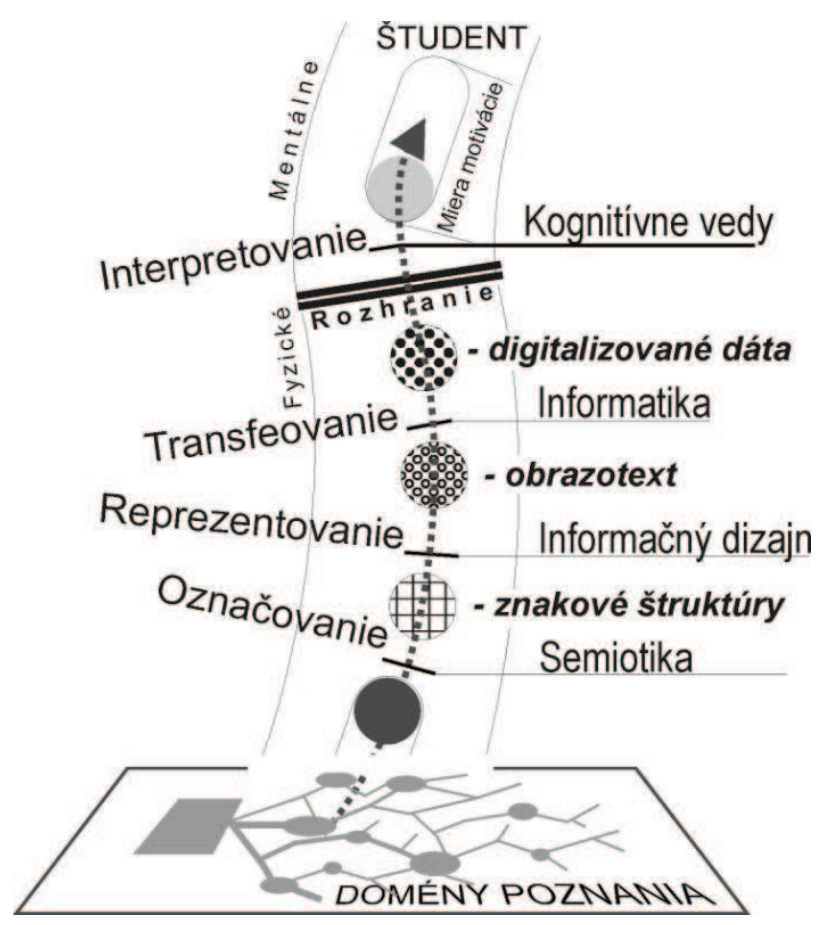

Obr 3: metamorfóza znaku v procese poznávania a odbory zainteresované na jeho analyzovani, formovaní, transferovaní, interpretovaní.

\section{Informačná hodnota znaku}

Spojenie slov z nadpisu tohto odstavca je pomerne vzácne, preto otvára možnosti viacerým interpretáciám. Aby sme zúžili rozsah synergie pojmov informácia - hodnota - znak na začiatku objasníme, čo jednotlivé pojmy v našej koncepcii zastupujú. Slovo informačný/á je vlastnost' odkazujúca na schopnost' informácie menit' tvar systému (lat. informare = utvárat', formovat'...). V našom prípade schopnost' určitým smerom a do istého času tvarovat' kognitívne významové útvary nášho vedomia.

V logike, matematike, či iných exaktných vedách sa chápe hodnota ako objektívna kvantita - číslo. V našej koncepcii vychádzame z predpokladu, že informačná hodnota zmenšuje neusporiadanost' systému (umelého aj mentálneho) a v konečnom dôsledku dáva procesom získavania vedomostí zmysel. Aby sme sa vyhli čistej formalizácii obtiažne redukovatel'ných procesov poznávania, včleníme do našej analýzy psychologicko-etický aspekt pojmu hodnota, ktorý do metódy vnesie humánny, noetický rozmer interpretácie znaku. „Hodnotu znaku“ na rozdiel od významu znaku, budeme potom chápat' ako komplex aktuálnych motívov, ktoré ovplyvňujú postoje, vnímanie a jednanie jednotlivca. $\mathrm{V}$ hodnote sa realizuje pragmatický postoj jednotlivca $\mathrm{k}$ svetu, cez hodnotu sa znak individualizuje. Z toho dôvodu je hodnota niečoho, na rozdiel od ceny, existencionálne individualizovaná.

V nasledujúcom uvediem síce excentrický, ale efektívny príklad, ktorý nám umožní demonštrovat' fúziu teórie informácie so semiotickými aspektmi pri analýze zdiel'ania informácií. Z dôveryhodného zdroja dostanete dlho očakávaný e-mail napísaný čínskym písmom. Nie ste síce vynikajúci sinológ, ale e-mail prečítate aj napriek tomu, že niektorým znakom nerozumiete - dokážete si ich význam odvodit' z kontextu. To čo prečítate je prekvapivo dôležité pre váš postoj $\mathrm{k}$ istému objektu, o ktorý sa zaujímate. Aj ked' ste takúto informáciu neočakávali, akceptujete ju pretože obsahuje len jeden vecný význam a pochádza z dôveryhodného zdroja. Otázka znie, aká je informačná hodnota tohto e-mailu?

Analýza: Syntax správy umožňuje znaky čínskeho písma identifikovat'. Nachádzajú sa v prehliadači e-mailov na konvenčnom mieste a usporiadaní. Znaky sú graficky reprezentované s primeraným rozlíšením a kontrastom. Sémantika znakov rešpektuje gramatiku čínskeho jazyka, preto za $35 \mathrm{~s}$. priradíte k znakom náležité 
významy, čím odseparujete od nosnej správy informačný obsah o vel'kosti 220 bitov. Ďalších 30 s. venujete overeniu iných významov. Celkovému porozumeniu neprekáža ani to, že niektorým znakom nerozumiete, čo svedčí o tom, že v správe je použitá užitočná redundancia [14]. vel'kosti 30 bit. Informačný tok je 3,84 bit.s $\mathrm{s}^{-1}$. Z pragmatického hl'adiska je informácia pre vás dôležitá $\left(\mathrm{x}_{1}\right)$, aj ked' nie je transferovaná preferovaným médiom $\left(\mathrm{x}_{2}\right)$. Nepravdepodobnost' obsahu síce spočiatku spôsobí neistotu a dočasne naruší váš mentálny model o objektem, ale po reštrukturovaní vzt'ahov a súvislosti sa poznatky o objekte rozšriria o d’alšie „možné“ vlastnosti formy bytia, dôsledkom čoho zmeníte počet a pravdepodobnost' vašich nasledujúcich reakciî $\left(\mathrm{x}_{3}\right)$. Informácia híbkovo zmenila postoj k objektu $\left(\mathrm{x}_{4}\right)$ až do „príchodu“ d'alšej kontextovej informácii.

Po zovšeobecnení uvedeného môžeme vyslovit' hypotézu, že informačná hodnota znakov sa zvyšuje úmerne:

1. vel'kost'ou informačného toku - množstvo bitov použité na prenos informácie za jednotku času je podmienená nutnost’ou zrakového orgánu identifikovat' znaky,

2. mierou užitočnej nadbytočnosti (redundancie) znakov. Redundancia síce obsadzuje priestor v médiu, ale pri komplikáciách na syntaktickej alebo sémantickej úrovni môžme rekonštruovat' pôvodná podobu [15],

3. mierou nepravdepodobnosti informácie Miera novosti odzrkadl'uje vel'kost' odchýlky od poznania spôsobov bytia, mieru zložitosti obrazotextu po obsahovej aj formálnej stránke,

4. poznaním pravidiel jazykového systému, v ktorom sa $\mathbf{k}$ znakom prirad'ujú významy. Každý z nás má iné dispozície na oddelenie obsahu od znakov. Povedané inak, pochopit' ten istý informačný obsah môže každý z nás individuálnym množstvom a typom znakov,

5. motiváciou $\mathbf{k}$ zdiel’aniu komunikovaného obsahu a afinita $k$ formám obrazotextu. Implicitnou podmienkou schopnost' umelého systému emitovat' žiadané informácie obr.3.

Každá z piatich premenných zhodnocuje odlišné vrstvy procesu poznávania. Zatial' čo prvú premennú môžeme presne kvantifikovat', pretože popisuje kadenciu istého média emitovat' kódy, d'alšie premenné sú viacmenej závislé na subjektívnom hodnotení adresáta. Druhá a štvrtá premenná hodnotí gramotnost', piata mentálnu vyspelost', vedomosti a individuálne preferencie a záujmy. Premenné 1-3 zhodnocujú silu znaku v jeho fyzickej podobe na premenných 4-5 participuje v plnej miere adresát, z čoho vyplýva, že dávajú znaku antropický rozmer obr.3.

Navrhnutá metóda zhodnocovania informácií ide nad rámec zaužívaných formálnych postupov. Jej nedostatkom je, že $\mathrm{v}$ súčasnosti nemáme $\mathrm{k}$ dispozícii inštrumentárium na kvantifikovanie tých premenných $\left(\mathrm{x}_{1}, \mathrm{x}_{2}, \mathrm{x}_{3}, \mathrm{x}_{4}\right)$, ktoré sú odvodené od fyzio-bio-sociálnej zameranosti jednotlivca. Respektíve, za súčasného stavu poznania vieme účinok premenných odhadnút' len $\mathrm{s}$ určitou mierou pravdepodobnosti. Alternatívou je poskytnút' čast' kompetencií na kvantifikovanie $x_{i}$ niekomu-niečomu tretiemu. Niečomu, čo nás pozná natol'ko, že nám dokáže optimalizovat' vel'kost' informačnej hodnoty.

\section{Informačná hodnota znakov $v$ procese poznávania}

Pri analyzovaní úlohy informačnej hodnoty znakov v procese poznávania podl'a uvedenej metódy dedukujeme, že informácie nespôsobujú kontinuálne znižovanie entrópie systému, resp. nespôsobujú kontinuálne vyššiu mieru usporiadanosti znalostí. Zložité, prekvapivé, šokujúce, ale aj informácie, ktoré ponúkajú alternatívy (napr. viac produktov $\mathrm{v}$ jednej cenovej hladine) zvyšujú entrópiu - neistotu v systéme. Až časom sa vplyvom homeostázy, prirodzenej schopnosti udržat' si integritu, systém v určitých medziach stabilizuje.

Poznávanie je dynamický proces neustáleho narušovania a zjednávania znalostí o označovanom, deštrukcie a konštrukcie, či tvarovania mentálnych modelov. Poznávanie je pulzovanie medzi konvergentným a divergentným myslením $\mathrm{v}$ rôznych úrovniach zložitosti, stabilita $\mathrm{v}$ chvení medzi racionálnym a emocionálnym medzi komplexným a detailným, s ciel'om znižovania neistoty vo výskyte náhodných udalostí. $\mathrm{Aj}$ v našej komparácii informačné vedy, ale aj exaktné všeobecne, preferujú paradigmu konvergencie, ked' sa snažia dospiet' $\mathrm{k}$ jednému komplexnému riešeniu, zatial' čo semiotika a humanitné vedy skôr uprednostňujú divergentné mapovanie v mozaike „menších“ ale viacerých právd.

\section{Záver}

V koncepte metavzdelávania je aktívne dávkovanie hodnoty informácií jedným z klúčcových momentov. Ešte sme d'aleko od stavu, ked' prichádzajúce znaky budú „vediet““ pružne reagovat' na aktuálne schopnosti a potreby účastníka. Priblíženie sa k tomuto ideálu 
znamená preskúmat' hlavne tie skryté premenné $\left(\mathrm{x}_{\mathrm{i}}\right)$, ktoré dokážu znížit' entrópiu odstránením krízových miest v systéme. V nasledujúcom výskume sa zameriame na premennú nepravdepodobnost' informácie, ktorú môžeme pri tvorbe obsahu a formy aktívne ovplyvňovat', napríklad cez paradox a oxymorón.

\section{Literatúra}

[1] STOLÁR, A. Meta-vzdelávanie. In Journal of technology and information education, Volume1, Issue 1, 1/2009, s.7-18, ISSN 1803-6805 (online), ISSN 1803-537X (print).

[2] HAVEL, I. Artificial Thought and Emergent Mind. URL: http://www.cts.cuni.cz/ havel/ work/ai-cvut.html., (online)1998.

[3] FLUSSER, V. Komunikológia. Mediálny inštitút, Bratislava: 2002, 253 s. ISBN 80-96877003.

[4] ČERNÝ, J., HOLEŠ, J. Sémiotika. Portál, Praha: 2004, 27s. ISBN 80-7178-832-5.

[5] BEČKA, J. V. Slovník synonym a frazeologismů. Vydavatelství Novinář, Praha: 1982. 463 s. ISBN 80-7294-071-6.

[6] MISTRÍK, J. Moderná slovenčina. SPN, Bratislava: 1983, ISBN 80-08-01042-8.

[7] (online) http://www.visual-literacy.org/ periodic table/periodic table.html

[8] ENGELHARDT, Y. The language of graphics: a framework for the analysis of syntax and meaning. Faculteit der Natuurwetenschappen, 2002, ISBN 90-5776-0894.

[9] KRESS, G., VAN LEEUWEN, T. Reading Images. London: Routledge, 1996, ISBN 978-0415-31915-7.

[10] CVIRK, O., et al. Art Fundamentals. Bowling Green State University, New York: 2001, ISBN 007-112144-7.

[11] (online) http://www.xmediapartners.com/ How_many_colors_can_the_human_eye_seeqna $2 \overline{0} 11$. html

[12] SILBERNAGL, S. a kolektív, Atlas fyziologie člověka. Grada Publishing, Praha: 2009, ISBN: 80-247-0630-X.

[13] VODÁČEK, L., ROSICKÝ, A. Informační management, pojetí, poslání a aplikace. Management Press, Praha: 1997, ISBN 8085943-35-2.

[14] ŠABOUK, S. et al. Umělecká informace. Československý spisovatel, Praha: 1989, 112 s. ISBN 80-202-0004-5.

Ing. Anton Stolár, ArtD.

Katedra výtvarnéj tvorby a edukácie

Pedagogická fakulta UMB

Ružová 13,

974 01, B. Bystrica, SR

Tel: +421 484464111

E-mail: astolar@pdf.umb.sk 